\title{
Multi-intertextuality Strategy in Donald Barthelme's Postmodern Writing
}

\author{
Fuhua Liu \\ School of Foreign Languages, Dalian Jiaotong University, Dalian, Liaoning 116028, China
}

Keywords: multi-intertextuality strategy, Donald Barthelme, postmodern writing

Abstract: The present paper analyzes the multi-intertextuality strategy employed in Donald Barthelme's postmodern writing. Intertextuality between text and reality, intertextuality between text and original text, intertextuality between text creation and text critique are analyzed respectively in detail. Through the analysis, the paper reaches its conclusion that as a responsible humanist and writer, Barthelme recreates a new reality in his text which is a proper comment on the reality he lives in by using his multi-intertextuality strategy.

\section{Introduction}

Donald Barthelme is one of the most influential American postmodern writers. Native critics mostly explore Barthelme's postmodern text from the angle of non-linear narration, fragment and collage principle, parody, play on language etc. in order to unveil typical postmodern features such as indeterminacy, absurdity and popularization. Native critic Li Yuping gives a full explanation of intertextuality employed in Barthelme's Snow White [1]. Other critics such as Zhang Man and Chen Junsong focus on parody, a writing strategy with intertextual features [2-3]. However, there is a total lack of systematic and deep-level comprehensive study on intertextuality in Barthelme's postmodern writing both home and abroad. Many critics have not been fully aware that as a writing strategy adopted by Barthelme, intertextuality aims to reveal and comment on the reality of the era the writer lived in.

\section{Body}

\subsection{Intertextuality between Text and the Real World}

What is reality? This is a term somewhat hard to define. Reality in Barthelme's day has developed tremendously and formed its unique features different from what it was in the past. The reality itself has become unreal, artificial, and even man-made. In a traditional society in the past, the world we lived in is kind of stable, an object that we can observe and comprehend. Literary works under this circumstance is and can be a reflection of the reality. In today's society, however, reality has somewhat blurred. The first feature of modern reality is its fictious quality. Reality is even more fictious than fiction. We live in a world that can shock even the most imaginative writers. Another important characteristic of modern reality in Barthelme's day is the flourishing of media, especially the popularization of the Internet. People are bombarded with all sort of information, true or false. 
The American government or some politicians make use of "language" to propagate their ideology and impose their ideas on the public. The artificial language in this situation becomes problematic, and thus fails to remain loyal to reality.

Barthelme's postmodern text is a delicate indication of reality in terms of economic, social and cultural occurrences. First, the new reality devalues meaning and values form. The emphasis on form in Barthelme's postmodern writing truly reflects this phenomenon. Some critics hold that Barthelme's text is filled with blague. In a sense, his text is nothing but "trash". Barthelme claims that the real world is a world full of trash, so instead of complaining the trash around us, we've got to appreciate it, something called trash aestheticism. Barthelme also purposefully plays games on language, leading to the destruction of meaning or content of the text. The writer's focus on language the form rather than content the meaning shows what is really happening in this very world---the devaluation of meaning and valuation of form.

In addition, we live in a most fragmentary world and thus think in fragments accordingly. Because of the fragmentary feature of the real world, we have difficulty pinning down truth in most conditions and comprehending the world in a thorough, systematic and comprehensive manner. In most cases, we can only perceive part of the true picture of anything. Paradoxically, with the development of high-technology, we begin to doubt just about anything and feel that everything seems to be uncertain. That explains why Barthelme's postmodern text is largely a collage of various fragments. Like the real world, the meaning in the text becomes uncertain. By using the collage principle, Barthelme manages to corner his readers by preventing them to get a full understanding of his writing. And he also succeeds in letting his readers experience what they have experienced every day in reality [4].

To a larger extent, Barthelme's text has become another reality, which parallels with the real world. There is a lot of interaction or intertextuality between his text and reality. In the traditional sense, art is from life and thus a reflection of life. Under the guidance of this literary theory, the real world is always the main body, and literary works are always subsidiary. In Barthelme's postmodern writing, however, things have changed dramatically. The reality continues to exert influences upon literary works of course. But at the same time, postmodern novels have become kind of independent, tending to exert equal influences upon reality. There is even the tendency that cultural media built by language or video such as postmodern novels can exert bigger influences upon reality in this real world dominated by digital devices.

\subsection{Intertextuality between Text and Original Text}

What is reality? We've got to raise the question again. Reality is what has become problematic and what is getting attention. In this sense, reality in Barthelme's modern era also refers to literature itself. The self-reflective nature of postmodern writing is what we call meta-fiction. The term actually shows postmodern writers' major responsibility as writers. That is, when literature ceases to be what it used to be, postmodern writers naturally respond by showing their attitudes and worries towards literature. In their writing practice, they show their dissatisfaction with the traditional literary works, especially fairy tales and other classics, because these works are all clichés that follow the same plot, which undoubtedly fails to reflect on and comment on the complicated modern reality. Meanwhile, they have great difficulty coming up with satisfactory works themselves. Their dissatisfaction with tradition and incapability of coming up with solutions to good writing inspire them to destruct classics, thus establishing intertextuality between text and original text and building dialogues between writers in their age and writers in the past.

As a postmodern writer, Barthelme faces the same obstacles in terms of literature creation. So he tries to parodize the traditional classics, making fun of the heroes or heroines in the classics. In this 
way, readers become disillusioned and rational after Barthelme's merciless revelation of the artificial nature of classics. After seeing through the man-made process of literary creation, readers no longer get indulged in the man-made plot of the sacred and touching stories. While the readers become more and more disillusioned, traditional classics are beginning to lose their charm bit by bit. Because of the complexity of modern society, readers can no longer appreciate the pure and upright traditional classics. For example, in Barthelme's major work Snow White, Snow White composes a poem. But the writer describes it as trash. In modern society, poets fail to sustain noble minds and thoughts and write out really noble poems, while readers also lose their humanity and interest in appreciating such poems.

\subsection{Intertextuality between Text Creation and Text Critique}

Writers all show their eagerness to comment on literature in their own writings. For example, Cao Xueqin in his masterpiece A Dream of Red Mansions shows his attitudes and ideas about poems by letting Lin Daiyu lecture Xiang Ling about how to compose poems. There is also predominant intertexuality between text creation and text critique in Barthelme's postmodern writing. Barthelme seems to criticize everything relevant to literature in his works, be it classical literature, philosophical views, scholars, psychological terms, literary theories or even postmodern writing itself.

We cannot conclude whether there is more creation or more critique in Barthelme's works. To a large degree, we can even say that his literary works are not at all products of creation but those of critique. Too much critique in his works makes his works lack literariness. We cannot help asking whether his works can still be considered as literature, because we cannot get the slightest aesthetic beauty that traditional literary works once gave us. When reading Barthelme's works, we readers have to use our brains rather than our senses. We can seldom be moved to tears or shocked to wide eyes or angered with green faces. The happy side of his works is that readers can really get insights into the essence of what is happening to the whole society, especially to the literary world. Thus Barthelme's works have attained their historical value, becoming works for coming generations to study so that they can learn quite a lot about every major aspects of the era the writer lived in.

\section{Conclusion}

The era Barthelme lived in had changed and evolved to its own peculiar fashion, so compared with traditional novelists, the means adopted by Barthelme must change accordingly. Through multiintertextuality, namely, intertextualtiy between text and reality, intertextuality between text and original text, intertextuality between text creation and text critique, Barthelme reflects and comments on reality. The paper breaks the limit of study on postmodernity. Instead, it explores the realistic elements in Barthelme's postmodern writing from a historical high stand and perspective. The conclusion is that Barthelme behaves as a realist in his own peculiar way. There is nothing unrealistic about him. His works embody strong social senses both as a humanist and as a writer. By using multi-intertextuality strategy, Barthelme recreates a new reality which is a proper comment on the reality he lived in.

\section{References}

[1] Li Yuping. Intertextuality in Donald Barthelme's "Snow White”. Foreign Literature Studies, 2004(6).

[2] Zhang Man. Parody of Classics: The Deconstruction and Rewriting of "The Glass Mountain". Foreign Language Education, 2007(5). 
[3] Cheng Junsong. The Replenishment of the Novel---Parody and Deconstruction in Fowles and Barthelme's Fiction. J. of Xuzhou Normal Uni. 2009(1).

[4] Patteson, Richard F., ed. Critical Essays on Donald Barthelme. New York: Macmillan Publishing Company, 1992. 